\title{
Plato's Statesman and Laws: Theory, Context, and Method
}

\author{
Ryan Balot \\ University of Toronto, Toronto, Ontario, Canada \\ ryan.balot@utoronto.ca \\ Hallvard Fossheim \\ University of Bergen, Bergen, Norway \\ hallvard.fossheim@uib.no
}

Most readers of Polis have encountered the dismissiveness traditionally shown toward Plato's Statesman and Laws: while the Laws is frigid or senile, nothing more than a collection of laws, the Statesman is 'tedious and jejeune', lacking in imagination or philosophical significance. ${ }^{1}$ Under the weight of this consensus, interpreters of these texts have conventionally begun with a round of sheepish apologia. The Laws (and a fortiori the Statesman) may never sparkle like the Republic, scholars confessed, but it has other virtues, they argued, such as its closer focus on the nitty-gritty of political rule. Quickly, however, self-justification has been transformed into self-confidence, as scholars began to uncover these texts' philosophical merits. Their work has restored Plato's Statesman and Laws to a deservedly prominent position alongside the Republic. Though less widely known and taught, these dialogues compellingly explore (among other things) questions of political knowledge, utopianism, the rule of law, the cultivation of civic virtue, and the quality of diverse regime types. They extend, comment upon, and often take issue with the ideas found in Plato's more familiar texts. Hence, while important in their own right, and for their influence on the later tradition, they also make essential contributions to the understanding of Plato's political philosophy as a whole.

Because of these salutary developments, contemporary readers find themselves in a considerably more favorable environment than in the past. This special issue itself speaks to the unabated interest in these dialogues over the

1 C. J. Rowe (ed.) Reading the Statesman: Proceedings of the Third Symposium Platonicum (Sankt Augustin: Akademia, 1995), p. 9. 
past several decades. It originated in the annual Bergen Ancient Philosophy Symposium of 2018, entitled 'Democracy and Its Rivals: Plato's Statesman and Laws'. Our authors can now anchor their investigations in a substantial body of provocative and eclectic scholarship. Previous work has clarified the dialogues' central lines of thinking, established foundations for our understanding, and raised questions that deserve further probing. The present issue of Polis builds on these foundations and draws special attention to questions of the political regime, both in general and particularly against the backdrop of the Athenian democracy. How do Plato's two dialogues relate to the institutions and practices of democratic self-rule, as they were known in Athens and elsewhere? How, moreover, do these texts reflect upon, criticize, or even extend the ideals of the ancient democracies? What is the character of their proposed alternatives? What, finally, are the best methods of thinking philosophically about these salient themes of political theory?

We would highlight, in particular, three frequently overlapping lines of approach in the papers that follow: contextual, cross-disciplinary, and literary. While these approaches in themselves are not new, the following papers employ them in novel ways. The result is, we hope, a set of fruitful readings that pose, and provisionally reply to, large questions about the politeia, philosophical method, and literary design in Plato's political texts.

An investigation of Plato's reflections on the regime, and particularly democracy, lends itself readily to a contextual approach, broadly construed. Whatever their precise dates of composition, Plato's Statesman and Laws were written against the backdrop of Athens' democratic politeia and its distinctive ideals, norms, practices, and institutions. Already in 1960, Morrow's seminal Plato's Cretan City had identified numerous borrowings from democratic Athenian ritual and institutional practice. ${ }^{2}$ Morrow's contextualism has given way, if not given rise, to a number of studies that investigate Plato's reflections on democracy in the Laws. ${ }^{3}$ With a more explicit focus on ethics and human psychology, for example, Bobonich argued that the Athenian Stranger's presentation of citizenship was deliberately more friendly to democracy than in Plato's other political texts. Samaras, on the other hand, emphasized the work's debt to 'Solonian Athens', while also detecting democratic features (such as 'checks and balances') and deeper democratic sympathies. Scholars continue

2 G. R. Morrow, Plato's Cretan City: A Historical Interpretation of the Laws (Princeton: Princeton University Press, 1960).

3 Including C. Bobonich, Plato's Utopia Recast: His Later Ethics and Politics (Oxford: Clarendon Press, 2002); A. Samaras, Plato on Democracy (New York: Peter Lang, 2002); M. Schofield, Plato: Political Philosophy (Oxford: Oxford University Press, 2006). 
to debate Plato's attitudes toward democracy in both dialogues, with many emphasizing critical elements and others ascertaining openness toward democratic political expertise (e.g., Sorensen 2016; cf. the essays in Rowe 1995). ${ }^{4}$ Either way, participants in these debates continue to draw attention to the democratic Athenian context in which questions of justice, political power, and the rule of law were continually explored.

In his magisterial 'Plato's Political Writings: a Utopia?', Luc Brisson takes up the question of Plato's 'utopianism', which arguably stemmed from a dissatisfaction with Athenian politics. Brisson argues that Plato's political writings criticize Athenian economic and political disunity; the city's social regulation of gender, sexuality, and marriage; its laws and juridical regime; and its imperialistic drives. Both the tale of Atlantis and the presentation of Callipolis (alleged in Critias and Timaeus to be the politeia of ancient Athens) were designed to further this critique. Setting out from the Seventh Letter, Brisson's startling claim is that Plato was not a utopian, but rather an 'impotent revolutionary'. Plato offered not imaginary solutions to political problems, but rather blueprints for political change. He intended to realize these changes in practice, either by transforming the politics of his native Athens, by inciting revolution in Sicily, or by founding a colony à la Magnesia. Rebuked for the radical proposals of the Republic, Plato modified his regime and created a virtuous and happy citizenry in the Laws. In the end, Plato failed in his political ambitions, which, however, could be pursued only in the democratic Athens of his time. Thereafter, despite his distance from any 'utopian' or unrealistic political aspirations, Plato was claimed as an authoritative 'utopian' forebear by writers, such as St. Thomas More, who could, because of their political circumstances, only dream of transforming politics in a just or rational direction.

Brisson's essay speaks to the heated controversies over Plato's attitudes toward democracy and constitutions, and to persistent debate concerning the character of Plato's utopianism. Offering a different presentation of Plato on law, utopia, and democracy, Anne Balansard's 'Le gouvernement de l'homme royal dans le Politique: une utopie assumée' finds that utopianism plays a key role in Plato's practical ideas of law and democracy. Balansard argues that political rule based on knowledge of the good, without laws, is a 'utopia', in that the good itself is impossible to realize in the sensible world. Insofar as they look toward the general welfare, however, the laws, even as empirically found, contain traces of the good. These observations lead Balansard to a striking inference: in the absence of the highest politeia, to imitate the regime ruled

4 Rowe, Reading the Statesman; A. D. Sørensen, Plato on Democracy and Political Technê (Leiden: Brill, 2016). 
by political knowledge means, paradoxically, to obey the established laws. Despite the deficiencies of law, Balansard argues, the best politicians, in practice, obey and cultivate obedience to laws that promote the common good. This understanding enables the Eleatic Stranger to separate out and condemn 'sophistical' regimes - that is, all existing regimes - in which political power serves the good of the ruler alone. While noting criticisms of Athenian democratic law and procedures, Balansard discovers a rehabilitation of democracy, and of law as such, that comes to sight only when we grasp the utopian character of the 'royal' political expertise.

Developing the theme of royal expertise, Hallvard Fossheim poses what may be the central question of political writers in and around the Athenian democracy: is the rule of one preferable to the rule of a few or the rule of many? This question was of special importance to the fourth-century political discourse of Plato, Isocrates, Xenophon and others. Reconsidering the Eleatic's distribution of offices and competences, Fossheim argues that, despite initial appearances, the text allows for a surprisingly broad basis of political rule. Fossheim acknowledges that the Eleatic typically refers to the politikos as a single individual or as 'kingly'. He also recognizes that characters throughout the Platonic corpus express intransigently critical attitudes toward the majority's capacities for political understanding. However, the logic of the Eleatic's arguments cuts in the other direction: for example, if the statesman should, ideally, supervise every aspect of an individual's life, then this ideal would be realized more completely if a larger number of statesmen were available. Moreover, the Eleatic's attempts to distinguish between the competencies of the statesman and his presumed subordinates end in perplexity. To achieve its goals, the Eleatic's regime requires a broader basis of rule by those with local knowledge and the capacity to direct projects to their completion.

If the politikê technê can be envisioned as distributed more broadly, then what is the precise character of political expertise according to the Eleatic Stranger? Among post-Aristotelian readers, one thought comes readily to mind: that the politikos possesses an 'architectonic' capacity to rule. By focusing on the metaphor of the 'architect', however, Melissa Lane mounts a powerful case against reading the Eleatic's theory through an Aristotelian lens. In 'Politics as Architectonic Expertise? Against Taking the So-called "Architect" (architektôn) in Plato's Statesman to Prefigure This Aristotelian View', Lane proposes to interpret that metaphor in its civic context, with special attention to the vocabulary and function of civic offices as known above all from classical Athens. This study leads her to emphasize the statesman's 'epitactic' function. By showing that the Platonic 'architect' is modelled on his civic namesake, she restores the statesman's supervisory and imperative role - that is, his role in 'ordering' 
the city for the best. This function emerges most clearly when the 'architect' is contrasted with other civic, and specifically democratic, officials, such as the logistês, a purely 'calculative' auditor of magistrates' accounts, attested in sources for the Athenian democracy.

Contextual interpretations of the Statesman and Laws can take a variety of forms, often involving literary engagement with contemporary writers as much as the exploration of legal and institutional practices. This strategy is more familiar from investigations of Plato's Apology, Gorgias, and Republic, but it has been recently applied to Plato's Laws with consequential results. In 'An Origin for Political Culture": Laws 3 as Political Thought and Intellectual History', Carol Atack illustrates the third book's intervention in debates concerning historical inquiry as a mode of political understanding. The salient context is intellectual history and contemporary education rather than political practice. In his presentation of early human societies, the Athenian Stranger implicitly criticizes Antisthenes' primitivism and his understanding of justice. As a theorist of the 'golden age', Antisthenes failed to recognize that the political experiences of early societies are irrelevant to discussions of justice in a more complex world. When he turns to the foundation of Sparta, the Athenian Stranger calls to mind the Isocratean interest in Athenian Laconophilia and Panhellenic warfare, but he eschews this approach in favor of using Spartan history to make theoretical points about the mixed regime. Altogether, the Athenian's critical engagement with contemporary writers aims at undercutting the value they place on historical exemplarity. His own vantage-point lies outside history, beginning with his account of Kronos' golden age, which provides principles on which a superior city can be founded.

In 'The Art of Politics as Weaving in Plato's Statesman', Kirstin Sampson unpacks the significance of weaving as the Eleatic's chosen image of statesmanship. She furthers the effort to connect Plato's political philosophy to gendered cultural activities in Greece and their representation in Greek literature and myth. For Sampson, the symbol of weaving draws the reader's attention to the essential corporeality of political life and to the problematic diversity which the political art necessarily confronts. In a conclusion with contemporary resonance, Sampson argues that the statesman's expertise cannot be rendered mathematically, through reducing political agents of diverse dimensions to regular and interchangeable units. Instead, the politikos requires finegrained judgment, involving temporal sensitivity and an awareness of the necessity of change.

Cross-disciplinary approaches have also helped us to connect literary appreciation to political philosophy with very different results. In Political Science, as opposed to Classics and Philosophy, readers of Plato often draw on the lines of 
inquiry established by Leo Strauss. Broadly speaking, Strauss's hermeneutical approach attends closely to the connections between drama, characterization, and philosophical argument; it treats theological arguments skeptically and politically; and it remains attentive to the dialectic between ancient and modern political thought. Several papers exemplify the advantages of reading these dialogues with and alongside Strauss-influenced interpretive strategies. In 'Sign of the Times: the Rise and Fall of Politics in Plato's Statesman', Charlotta Weigelt builds on Straussian approaches in order to bring to light an unforeseen dialectic between ancient and modern thought. For Weigelt, the dialogue is not so much an intervention in fourth-century controversies as an investigation of the possibility of politics altogether. The Eleatic conducts this investigation by distinguishing sharply between the golden age and the present age of Zeus; his method is broadly 'historical'. Nowadays, statesmanship construed as phronetic care (sketched, for example, by Sampson) has become impossible. Instead of creating a space for human freedom, humanity's need to rule itself has, perhaps paradoxically, brought about a reductive vision of the political art as nothing more than technical expertise. The quasibureaucratic, and certainly technocratic, model of power that results hardly merits the honorific title 'political' at all.

These sobering reflections on freedom and political judgment cast Plato's political philosophy in a pessimistic light. Is it appropriate to understand the Platonic texts as inviting a sanguine, or rather a tragic, perspective on the possibilities of politics? Ryan Balot takes up this question in another treatment that blends lines of inquiry established by Strauss and other political theorists with more traditional classical scholarship. In 'Polis and Cosmos in Plato's Laws', Balot argues that special attention to drama and characterization helps us to appreciate more fully the Athenian Stranger's strategies of educating his Dorian interlocutors. Balot inquires specifically into the Athenian's argument, in Book 10, that a materialist cosmology underpins the opposition of nature to convention and apparently sanctions unjust desires to acquire power over others. While materialism and tyranny may not be logically connected, they are psychologically connected in the minds of the Dorians. The Athenian is sensitive to the Dorian characters' implicit belief that politics operates - and should operate - according to the antagonistic motions that are, apparently, the foundation of all nature. In light of this sensitivity, the Athenian's theology should be interpreted as a thickly constituted religious ideology designed to moderate Kleinias' aggressiveness and desires for power. His act of political foundation is informed by the rhetorical use of religious myths. 
In 'Herdsmen and Stargazers: the Science of Philosophy in Plato's Statesman', Olof Pettersson reads the dialogue as a critical test, not of the Eleatic's technocratic vision of politics, but rather of his 'scientific' method of identifying the politikos. Like Strauss, Ferrari, and others, Pettersson draws attention to the distinction between the author and his characters - even, in this case, the undisputed protagonist. Building on similar approaches to Plato's Sophist, Pettersson shows that the Eleatic's treatment of eugenics, tyranny, and law undermines the very reasoning that enables him to conclude with a definition of the statesman. For example, if the politikos arranges marriages and breeds citizens who are both moderate and courageous, Pettersson argues, then the distinction between divine and human carer for the human herd is lost. Similar problems bedevil the Eleatic's distinction between the statesman and the tyrant and his reflections on the need for law. Pettersson's arguments have far-reaching implications for all those who have previously argued that this dialogue provides a viable or attractive notion of political expertise.

In his examination of method in Plato's Statesman, entitled 'Differentiating Philosopher from Statesman According to Work and Worth', Jens Kristian Larsen argues against the suspicious, if not subversive, conclusions characteristic of Strauss-inflected scholarship. For Larsen, the Eleatic's use of collection and division is not only capable of distinguishing statesman from sophist, but also of reliably explaining, with reference to objective criteria, why the statesman's activity, though significant, is worth less than the philosopher's. Accordingly, even if it may be limited in its capacity to offer a complete definition of the sophist, statesman, and philosopher, collection and division is far from a value-neutral approach to such inquiries.

While this special issue does not present a unitary interpretation of either Plato's Laws or Statesman, our authors have, we believe, raised novel and significant questions. In so doing they have uncovered paths that will reward future investigation. Whatever the diversity of their approaches, they have converged on the necessity of pursuing fault-lines in the texts themselves. Far from being insipid, monotonous, or chaotic, these dialogues teem with ideas and are at times mysterious. Now more than ever, it seems critical to explore their internal contradictions and their potentially fertile ambiguities. In their respective ways, Laws and Statesman pose questions not only about politics, but also about themselves - about their literary design as dialogues and dramas, about their historical embeddedness, about the status of their allusions to other Platonic texts, about their intellectual and political ambitions, and about the epistemic standing of their conclusions. To the extent that it succeeds, this 
collection will inspire further efforts to enrich our understanding of these demanding, abundant Platonic texts.

As these papers were being finalised, Polis received a submission from Jeremy Reid, listing the offices of Magnesia. This paper will be a useful resource for those less familiar with the Laws, and provides a fitting appendix to the special issue. 